\title{
A CRITICAL ANALYSIS OF THE POLITICAL DISCOURSE OF EXCEPTIONALISM IN THE AMERICAN SNIPER MOVIE
}

Hamdallah Akvani :: Abdolvahed Zarifi :: Hossein Fakhraei

ORIGINAL SCIENTIFIC PAPER / DOI: https://doi.org/10.20901/ms.11.21.2 / SUBMITTED: 23.5.2019.

\begin{abstract}
Political discourse usually tends to diffuse itself in other discursive fields. One of the areas through which the political field can be reproduced is the field of popular culture, especially films. Moreover, language serves as the intermediate variable in which political discourses in the media offer themselves more or less ideologically. In this paper, the language of the film American Sniper and its relation to the exceptionalism discourse in the politics of the United States is reviewed. It addresses the major question of how the discourse of American Sniper is related to the three layers of exceptionalism discourse. The analysis of the three discursive levels of description, interpretation and explanation of the film based on Fairclough's model reveals that, by following Hollywood's dominant framework of discourse towards Islam and the Middle East, i.e., the 'Islamophobia' discourse, the film depicts Islam as 'Other'. The discourse of the film ultimately resides in a wider social action that is congruous with the concept of the political language of exceptionalism.
\end{abstract}

\section{KEYWORDS}

ISLAMOPHOBIA, EXCEPTIONALISM, POLITICAL FIELD, CRITICAL DISCOURSE ANALYSIS, AMERICAN SNIPER

Authors note

Hamdallah Akvani :: Department of Political Science, Faculty of Humanities, Yasouj University, Yasouj, Iran :: akvani@yu.ac.ir

Abdolvahed Zarifi :: English Language Department, Faculty of Humanities, Yasouj University, Yasouj, Iran :: vzarifi@yu.ac.ir

Hossein Fakhraei :: Department of Political Science, Faculty of Humanities, Yasouj University, Yasouj, Iran :: hosseinfakhraee72@gmail.com 


\section{INTRODUCTION}

With the collapse of the Soviet Union, the notion of exceptionalism in Western political discourse, especially in the United States, has become more prominent than ever before. Exceptionalism emphasizes that the West's experience is the most evolved, institutional, instrumental, and the like. The idea of America's exceptionalness has existed since the beginning of the discovery of the American continent and seems to be an inseparable part of political culture and the dominant belief of the Americans. Western discourse has come to take as a testimony to its claim of exceptionalism the fall of the Soviet Union, on the one hand; it, on the other hand, needed a new 'Other' to legitimize itself. Therefore, to fill in the vacuum of communism as 'Other', the Western policy came to voice the danger of Islam as an emerging power. Galvin (1993), the former commander of the NATO forces, observed, "We won the Cold War against communist Russia; now we can return after a seventy-year devastation to our true 1400-year-old struggle, which is confronting Islam". Hence, the communist threat could not justify the US policy of internationalism, and the United States needed to create a new enemy. To this end, 'Muslim terrorists' appeared to be an ideal example because they could serve as a plausible excuse for the imperial conquest of the Middle East and Central Asia (Ralph, 2006), and Islamism was, therefore, known as "the new bolshevism" (Thatcher, 2002). Similarly, some experts like Nye and Joseph (2004) believe that Americans assigned Islam a role that was once performed by communism and the Soviet Union. Emphasizing the institutionalized belief in the superiority of Western experience over others in Western political discourse, Ibrahim (2010) holds that "The American media played a major role in this distortion since their reporting of Islam often fuels stereotypes, hysterical fear and violence, and focuses on crisis coverage".

After September 11, there appeared a resurgence of a wider and stronger wave in the arena of politics and the media with Bush (2001) announcing that "the Crusades" had begun once again. In addition, the American think tank, Fukuyama (2001) emphasized that Islam is the only cultural system that threatens Western modernity. In the same way, Cohen (2001) observes that the US and its allies' war with Islam is the fourth world war. Karim (2006) argues that after the devastating Muslim anti-US attacks on September 11 , Muslims are generally portrayed in the United States as the occupants of a position previously occupied by communists. Muslims are generally viewed as the 'Other' that the collective 'Self' should be prepared to fight against (Poole and Richardson, 2010).

The Islamophobia operation was initially pursued as a campaign against violence and assassination terrorism, but the political activists in the West failed to justify their corresponding actions in the public mind as acceptable, mandatory and legitimate until September 11. Therefore, September 11 can be considered as a turning point in influencing the international system and the political language of Western media in a fundamental way. This incident has been particularly effective in creating a new language and sign, and finally in the formation of a fearful discourse of political Islam and the dissemination of the discourse of exceptionalism. The important point is that the language of exceptionalism was not limited to Western politics; it was rather reproduced and diffused in all the 
intellectual and social arenas, especially in the media. It should be pointed out that the American media and cinema, as an important section of popular culture, played a major role in this regard. Hollywood cinema is, for example, one of the US media systems, with some of its products aligned with the political arena in which the political language of exceptionality is normalized, and it appears to be consistent with common sense. American Sniper is one of the media products worthy of consideration in this regard.

\section{THEORETICAL FRAMEWORK OF THE STUDY}

The theoretical framework of this paper follows the semantics system approach. Walter Benjamin defines the system as "a cluster of theoretical and conceptual elements that are arranged together, but not intertwined" (Jay, 1984: 15). Therefore, we have employed propositions from exceptionalism theory, the Clash of Civilizations and Orientalism as the semantic system. The semantic appeal of these theories is their attention to culture and its relation to the logic of 'Self/Other' as well as the role of the language of popular culture in the reproduction and dissemination of binary opposition culture through exceptionalism.

Tocqueville is credited with being the first to describe America as 'exceptional'. He observed that Americans enjoy a totally exceptional position, holding that not any democratic nation can gain such a status (2003). Earlier in 1630, Governor John Winthrop (as cited by Sardar and Daveis, 2003: 151) announced, "We must consider that we shall be a City upon a Hill, the eyes of all people shall be upon us". The idea of exceptionalism was also expressed in "Manifest Destiny", which is actually a philosophical foundation for American dominance. According to Sardar and Davies (2003), the idea of "Manifest Destiny" was first introduced by the controversial theorist, O'Sullivan, who contended:

We are the nation of human progress, and who will, what can, set limits to our onward march? Providence is with us... All this will be our future history, to establish on earth the moral dignity and salvation of man the immutable truth and beneficence of God... (O'Sullivan, 1839: 426).

As Wilsey (2017) observes, O'Sullivan developed a specific type of Christian nationalism, known as "Manifest Destiny". In "Manifest Destiny", they believe American culture is the saviour of democracy, human rights, and a summary of human ethics and ideals in the world. This stance is also echoed by Melville (as cited in Garaudy, 2004: 5), stating "Americans are a special, superior nation and the Israeli of the age who are leading the ship of freedoms". Lamenting this discourse, Zakaria (2008) points out that this particular type of nationalism has always baffled Americans, making them believe that they are genuinely trying to empower other countries to improve their situation when they are fighting wars outside the US.

Referring to such a discourse as Europe-centred, Sayyid (2015) wrote that the discourse of Eurocentrism is an attempt to introduce the West as a universal example for the world, a project to revive the centrality of the West. This project, however, can exist when the West and centrality are considered synonymous. The result of such a cultural attitude is, in fact, missionaryism in the sense that the United States considers its experience as exceptional, 
assuming a great mission for itself, through which other societies, especially the backward ones, can be saved. Callahan (2004) considers this discourse as one of the main discourses in the West-American relationship with others. In line with this logic, the US imagines a God-given responsibility for itself in its foreign policy and concludes that if anything were good for America, it would undoubtedly be good enough for the rest of the world (Cox, 2003). America is also viewed as a city upon a hill with a beacon light serving as a guide for people loving freedom across the world (Robinson, 2015; Szpunar, 2013). It appears to be an advanced society whose values, philosophy and investment are based on freedom and a scientific and pioneering stand (Rojecki, 2008).

In the final analysis, Huntington's cultural theory of The Clash of Civilizations? remains in line with the political discourse of exceptionalism. In this theory, with a focus on culture, the Islamic world is represented with characteristics, such as intolerance, violence, intellectual retardation, and absolute pessimism towards the West. Furthermore, Islamic societies are uniformly marked and described as radical, violent and ideological. To Huntington (2000), among all the various civilizations and religions, Islam and the West (Christianity) have always been prone to hostility towards each other, and future wars will occur between these two civilizations.

Said's Orientalism (1979) is an attempt to represent this binary logic of Western exceptionalism. He argues that various works of the Orientalists have failed to enjoy any independence. In addition, their one-sided interpretations have inclined them towards Western domination, and Orientalism has come to serve the colonization (Kilani, 2008). Said believes that such Western stereotypical images about the Orient as inferior, backward, and ignorant are deeply rooted in the old tradition of colonialism culture. As such, Islam has always been considered as a major threat to Western society and has been looked at with fear and hostility. Said, in fact, views the West cultural attitude towards the Arabs as an outrageous attitude that is quite hateful and reminiscent of the theory of 'Same and Other'. What makes Said's viewpoint about Orientalism significant is his emphasis on the role of popular culture, such as novels, travelogues, newspapers, magazines, etc. in disseminating the cultural system of exceptionalism and Islamophobia. To save space, we have presented the binary opposition of Orientalism discourse as described by Said (1979) in Table 1.

Table 1. Binary Opposition of Orientalism Discourse

\begin{tabular}{ll} 
Framework of Same Representation (West) & Framework of Other Representation (Orient) \\
Development and Modernization & Backward and Retrograde \\
Tolerance and Patience & Prejudice and Violence \\
Peace seeking & Evil and Bellicosity \\
Rationality and Accountability & Madness and Extremism \\
Victim of Terrorism & Promoting Terrorism \\
Freedom of Women & Oppression of Women \\
\hline
\end{tabular}


Tracing the instruments that the Western society has employed to diffuse its discourse, Said comes up with the idea that in the new world, popular culture plays a great role in this regard and emphasizes that the West has always tried to raise the positive self-image of the West against the Oriental negative self-image of 'Other' in the media. Consequently, to most Americans, "Islam was nothing but Trouble" (Said, 2008: 11). Interestingly enough, the mass media stereotypes of Islam and Arabs do nothing but strengthening the Orientalist discourse that historically introduced "the Orient as uncivilized, primeval, primitive, and inferior to the West" (Menchawi Fawal, 2013: 3-4). It should be pointed out that this very association of the entertainment media with the Islamic Orient in Hollywood films is not only for amusement purposes (Menchawi Fawal, 2013: 3-4); it rather tends to "(un)consciously build unbefitting images of the East and portray it as a monolith of an inferior status for the common viewer in the West" (Ullah and Shahzor, 2017: 171).

In sum, knowledge of Orientalism stands as the key to the recognition of the representations in social and political discourse and clarifies the ideology behind them. As Zhang and Li (2017) point out, the most powerful tool of communication to which social actors have access is language that is replete with ideological concepts, values, and patterns. Of main concern to these three theories, therefore, is their attention to culture and its role in disseminating the semantic system of a discourse. In other words, the manifestations of popular culture like novels, newspapers, television, cinema, etc. reproduce and endorse the social structures and discursive system of exceptionalism and Islamophobia. Emphasizing this central role of the media, Williams (2000) uses the metaphor of magic for the media and media advertisement as part of the popular culture because the media convert different types of goods into mere symbols (linguistic and visual), and present discourses to the audience in highly organized forms of satisfaction and persuasion.

In fact, the main elements of magic are the linguistic and visual cues. Emphasizing the same role of language in cultural processes, Danesi (2009) considers language as the main and intermediate variable of us/them polarization. Following Danesi, Hervic (2015: 68) argues "oppositional cultural logic is based on bipolar logic between 'us' as similar and 'them' as different and therefore incompatible. In all 'us'/'them' divisions, there is a totality of unequal bipolarity: the 'us' (the 'we-group' or 'in-group') is valuated positively and superior, 'they' ('out-group') are associated with negativity and inferiority".

In a similar way, Pierre Bourdieu (1991) sees language as a key element in cultural and political fields since language is an intrinsic element of cultural reproduction processes that directly and indirectly play a very important role in the reproduction of the established social order. Bourdieu maintains that the classifying power of language is the foundation of any cultural production. These classifications are by no means politically and socially neutral but they are intertwined with power relations and language in various areas of culture, the media, etc. and function as a tool for the continuation of social and political power. 
From among different forms of the media, Danesi holds that movie and cinema are the most important part of the popular culture in imaging in the contemporary world, emphasizing that "[n]o other media stage has stimulated as much artistic creativity as has the movie screen. And no other art form has had the capacity to hold up a mirror to the contemporary world as has cinema" (2012: 235).

The same view holds for Hollywood cinema. Although Hollywood cinema is not all the US industry and its popular culture, it plays a very important role in forming the American and world popular culture: “US films are shown in more than 150 countries worldwide, and American television programs are broadcast in over 125 international markets" (Wasko, 2003: 175). This is because many analysts view Hollywood cinema as an important part of American popular culture whose language of production is filled with the system of cultural symbols of American society. According to Hebdige (1988: 74), "American popular culture - Hollywood films, advertising images, packaging, clothes and music - offers a rich iconography". As a result, Hollywood, as one of the most important pillars of American popular culture, offers texts full of symbols (linguistic and visual) that influence American culture on the one hand, and build on that culture on the other, and tries to globalize and present its products homogeneously in line with the American discourse.

\section{METHODOLOGY}

This paper examines the socio-political function of language as an intermediary variable in the process of disseminating political culture discourse through movie as part of popular culture. By analysing American Sniper as an example of the Hollywood war cinema, the current paper tries to reveal the interactive relationship between political culture and cinema products as part of popular culture. To this end, Fairclough's framework of discourse analysis was used as an important approach of critical discourse analysis. This analytical approach illustrates how discourse of exceptionalism and Islamophobia about the 'other' is reproduced and disseminated through the variable of language.

This study employed a purposive and non-random sampling which is the most common type of sampling in qualitative analysis with the purpose of gaining a deep understanding of the phenomenon under study (Chava and Nichmias, 2000). American Sniper, as the sample of the study, was reported to be a top and most watched film in the United States, the Middle East and all over the world. The film was widely distributed in the world; it was the topic of discussion of the day in the world and in the Middle East. The film is also one of the most important products in the history of Hollywood cinema in terms of its audience and the awards and revenue it received (Epstein, 2015).

The negative image of Islam portrayed in the film created massive feedback in the Muslim world, including some criticisms made by the leader of the Islamic Republic of Iran, who believed that the film encourages the persecution of Muslims (Khamenei, 2015). It also motivated two Egyptian directors, Amr Salama and Hany Abu-Assad, to make a movie called Iraqi Sniper as a retaliatory measure against American Sniper. Similarly, the 
American-Arab Anti-Discrimination Committee asserted that threats against Muslims and Arabs had increased after the release of American Sniper, a very popular but controversial film (Karizat, 2017). The film was also reviewed as a cinematic fun about a killing machine with a heart of gold which slowly begins to feel bad for shooting a large number of innocent women and children (Taibbi, 2015). Moreover, this film was selected as the sample simply because it fits for analysis within the framework of critical analysis and can serve as an appropriate case for revealing the foundations that make up this approach.

\section{ANALYTICAL FRAMEWORK}

To understand the natural discourses in American Sniper, Norman Fairclough's Critical Discourse Analysis (CDA) was used. A central aspect in this method of discourse analysis is that discourse is considered as an important form of social practice that reproduces and modifies knowledge, identities, social and power relations. In Fairclough's CDA, factors such as historical context, power relations, cultural, social, and ideological institutions create a text or a linguistic form and meaning that make discourses. In this process, language has an important role to play because it is a core component of cultural and political struggles and has a lot to contribute to the reproduction of social order both directly and indirectly. As a result, language helps the classification of social groups. In line with the above arguments, examining the micro-level language in any text is essential for the study of social and cultural changes. It is perhaps for the same reason that Fairclough (1989: 4) describes the objective of this approach as "a contribution to the general rise of consciousness of exploitative social relationships, through focusing on language". Of course, Fairclough (1992) finds text analysis alone insufficient for discourse analysis since it fails to shed light on the possible connections that exist between texts and their related social and cultural structures. He, therefore, developed the following three-dimensional model for discourse analysis.

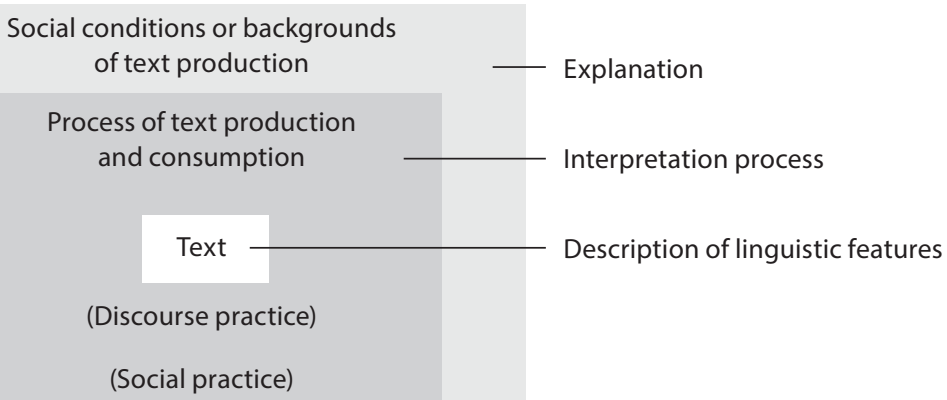




\section{AMERICAN SNIPER IN A GLANCE}

American Sniper is a biographical war drama that was scripted by Jason Hall. It is based on the book American Sniper: The Autobiography of the Most Lethal Sniper in U.S. Military History and directed by Clint Eastwood in 2014. The movie begins with the voice of the Azaan (Call for Prayers) and ends with displaying the American flag, implying that Islam and Muslims begin the war, and the United States ends and wins the war. This is the general message of American Sniper, a film in which Muslims serve as evil terrorists; people who send their little children with bombs to fight against American forces; and their women hide weapons under their covers. It, on the other hand, portrays US troops to be unwilling to shoot even the dog that has disrupted their mission. American soldiers are shown to be human beings whose all concern is establishing world peace and protecting the safety and security of the Americans. The film's protagonist, Chris Kyle, is a cowboy who sees the security of his country at risk by seeing the scene of an attack on the US embassy in Nairobi. He joins the army to protect the safety of the Americans. He spends months and years away from his wife and children fighting in Iraq. Chris Kyle is finally murdered after being retired from the military in a shooting practice by a soldier who was also wounded both physically and mentally in the war.

\section{FINDINGS OF THE STUDY}

Drawing upon the system of concepts and propositions of the three theoretical traditions of exceptionalism, the Clash of Civilizations and Orientalism, the American Sniper movie, as a text, is described at the three levels: description, interpretation and explanation. In this section, we will first deal with the film script and its linguistic analysis; next, its discursive practice and finally its social practice are accounted for in detail.

\section{DESCRIPTIVE LEVEL}

One of the key issues that should be taken into account at the level of description in discourse analysis is vocabulary syntagmatics and paradigmatics which were first used in linguistics by Saussure. Saussure (1916) stresses that meaning is created through the difference between the signifiers which are either syntagmatic, concerning position, or paradigmatic, concerning substitution. Syntagmatics is the horizontal axis of speech, in which the components of the speech are adjoined to each other, establishing a relationship of affinity. Paradigmatics, on the other hand, is the vertical axis of speech in which the components substitute each other, establishing substitution relations. As Saussure (1916) observes, syntagmatics and paradigmatics work together to create some structural context in which signs make sense. The dialogues of American Sniper are based on binary oppositions that regulate the syntagmatic and paradigmatic relations. Linguistic signs are also at the level of the purposeful relationship and based on mapping a bipolar space: 
MARC: Welcome to Fallujah. The new Wild West of the old Middle East.

Major: I want you to put the fear of God into these savages.

Chris: There's evil everywhere.

Chris: You want these motherfuckers to come to San Diego or New York?

The soldier: Let's go kill this fucker.

Chris: Those bad guys ended up in Sadr City.

Soldier Friend's: You know that kid could've taken out, like, ten fucking Marines, right? You did your duty.

Officer: And you're a patriot.

Chris: Yes, sir.

The soldier: Here he comes. Ladies and genitals, listen up! We have a legend in our midst.

Taya: You don't know when to quit. You did your part. We've sacrificed enough. You let somebody else go

Chris: Babe, I couldn't live with myself if I did.

Chris: I have to serve my country.

The action of the film dialogues at the syntagmatic level of such words as "wolf", "savage", "evil", "fucker" and "bad guy" induces a negative meaning to describe Muslims. In contrast, the co-occurrence of words such as "duty", "sheepdog", "patriot", "legend", "sacrifice", and "service" suggests a kind of positive meaning to describe American soldiers. The linguistic signs of the texts have a positive pole, which is an expression of 'Self discourse', representing United States. It has a negative pole representing and rejecting Islam, attempting to establish a causal relationship between Islam and 'negative affair'. As a result, there is a clear polarization between Americans as 'Self' and Muslims as 'Other'. In addition, it is seen in the syntagmatic axis of the film that the discourse follows a special purpose by ignoring the positive words and phrases for Muslims that are absent in the text.

In the first sequence, Chris Kyle shoots a boy and his mother dead because they wanted to hurt the American forces with a grenade. In another sequence, a boy picks up a gun to shoot at the American troops, but when he puts it down, the American soldier feels comfortable and at ease. In another sequence, the American troops postpone their operations simply for the sake of a dog. The co-occurrence of these visual signs suggests that Americans maintain a superior and fair position for themselves, and that they even care about the rights of animals. They, however, come to kill the civilians and children only when the life of an American is in danger, and they, therefore, are forced to take action. In contrast, the analysis of various sequences reveals that Muslims do not even have mercy on their fellow citizens. In another sequence, the extremists torture and kill an Iraqi family for collaborating with Americans; they use their women and children for terrorist operations. They are still seen in another sequence to sell their fellow citizens only for money. The co-occurrence of these incidents produces a negative meaning for Muslims and legitimizes the presence of the US forces for security reasons. In the visual signs of the text, two classes of Western and Muslim social forces are reproduced with the first group as the 'Self' pole, depicted as family-friendly, with national and international commitment, peaceful, and security guardian, and the second group as the 'Other' pole who are violent, militant, anti-security, lacking in national commitment and mercy. Image signs also imply 
a semantic value of a binary opposition strategy (legitimate/illegitimate). Based on this strategy, part of the Muslims is suppressive and suppresses another part of the society, while the second part lacks the means of resistance and a legitimate power, tending to imply that the West and the United States of America must take measures for their release. The language signs along with image signs try simultaneously to show the power of the first group as something legitimate, depicting it in the public eye as such, and, on the other hand, to legitimize the power of the West in an occupied country, depicting it as something favoured by the public. All these descriptions reveal the discourse practice in which the film was produced.

\begin{tabular}{l|l} 
& Paradigmatic Axis \\
Muslim + Wolf + Savage + Satan + Bad & $\begin{array}{l}\text { Status quo } \\
\text { Possible }\end{array}$ \\
\hline Syntagmatic Axis &
\end{tabular}

$\Delta$ Figure 2 .

Syntagmatic and Paradigmatic Axes of American Sniper

\section{INTERPRETATION}

At this level, the practice and the discourse order governing the film and its use in language as well as the film genre and its intertextuality aspect are emphasized. There are generally two major Hollywood trends in relation to Islam, and particularly towards the war in the Middle East. One trend belongs to the discourse of Islamophobia and the other has to do with the discourse of 'peace and anti-war'. There happened to be a similar conflict during the Vietnam War that ended in favour of the hegemonic superiority of the discourse of 'peace and anti-war'. After the Cold War and with the replacement of Islam for communism, there emerged a new discourse conflict. At the outset, no one could imagine that the Islamophobia discourse would find a hegemonic position, but the September 11 event, as the 'semantic opportunity structures', led to the hegemonic superiority of this discourse and led to the marginalization of its opposite discourse. A careful review of the discourse of American Sniper reveals that the film stands in the dominant position and has resulted in the production of hundreds of films with a common theme, a phenomenon which is very important in terms of intertextuality.

Examining over 1000 films from the earliest Hollywood productions, Shaheen (2012) comes up with a dangerous and consistent pattern of stereotypes of a hateful Arab depicted in these films. He reports that Muslim Arabs have been pictured as the most notorious group in the history of cinema, featuring excessive negative stereotypes that exceed "negative images of Blacks, Native Americans, Asians, Hispanics and Jews" (Shaheen, 2012:12). In Frantic (Hampton et al., 2004), Muslim terrorists are pursuing the 
explosion of the statue of freedom by atomic bombs. Similarly, True Lies (Cameron et al., 1994) narrates a group of Arabs and Iranians who are engaged in a conspiracy to carry out a nuclear explosion in the United States, and Arnold Schwarzenegger, the militaristic hero of Hollywood films and the star of the movie, finally succeeds in defeating all the conspiracies and destroying the extremist Muslims. In addition, The Siege (Obst and Zwick, 1998), which was shown after bombing the city of Oklahoma, USA, portrays the story of the terrorist explosions in New York City. Later, Taken (Besson and Morel, 2008) tells the story of stealing the daughter of a CIA security officer by Muslim smugglers. In this film, Muslims are criminals, corrupt and bad guys. Next, Cleanskin (Hajaig and Hajaig, 2012) deals with the assassinations and chain explosions in London that are performed by a ruthless Islamic group with anti-imperialist and anti-West notions. This film also takes a very positive look at the Western military incursion into the Middle East. Then The Hurt Locker (Bigelow, et al., 2009), which patriotically justifies the military presence of the United States in Iraq and Afghanistan, is, in fact, disguising this presence with a humane and emotional attitude towards war and endorses the Pentagon's policies in the region. The Dictator (Cohen et al., 2012) has suggested that Muslims are seeking nuclear weapons, supporting terrorists, and that only the American democracy can free the people living in Muslim countries. Furthermore, in Zero Dark Thirty (Bigelow et al., 2012), this approach justifies the torture and harassment of prisoners accused of terrorism. Moreover, in Five Minarets in New York (Tokat et al., 2010), Muslims are introduced as groups of people that gather around under the guise of religious rituals to plan terrorist operations and donate money to other Muslim terrorists. Finally, Hollywood film makers like Samueles, Wizan, Lenart, Elders and Furie (1986) in Iron Eagle, Neufeld, Rehme and Noyce (1987) in Patriot Games, Reiner and Reiner (1995) in The American President, Belgrad, Cantillon, Handleman and Banks (2019) in Charlie's Angels, and others provide a violent image of the Muslims. These films have all been made around the core concept of Islamophobia and the reproduction of a new enemy. They tend to expand such related concepts as war for democracy, fight against terrorism and the inhibition of Islamic fundamentalism. The semantic implications of all these films ultimately represent the Western experience in terms of power, wealth, security, human rights, humanism, and the attempt to stabilize the notions of the political discourse of exceptionalism. As depicted in Table 2, in these films, the attributes that belong to the West or 'Self' are positive and ideal. In contrast, the attributes that belong to Muslims or 'Other' are all negative which fills up the life of the Oriental Muslims.

In American Sniper, the presence of Chris Kyle in the US military is first justified by terrorist groups bombing in US bases, and later the dispatch of Kyle and other US troops to the Middle East after the September 9 incident is broadcast on the TV. The incident indicates that Muslim groups started the war and forced the United States to send troops to create peace. Therefore, the bellicosity of Muslim groups and the peace-loving of Americans appear to be the dominant theme in Hollywood films. 
Table 2: Binary discourse of Exceptionalism in American Sniper

\begin{tabular}{ll} 
West or Self & Middle East or Other \\
Peace loving & Militant \\
Victim of terrorism & Terrorist \\
Merciful, kind-hearted & Merciless, cold-hearted \\
Global & Group oriented \\
Patriotic & Traitor \\
Developed & Backward \\
Guardian of society & Sabotage \\
Security guard & Deteriorating security \\
Courageous & Coward \\
Victorious & Defeated \\
Powerful & Weak \\
\hline
\end{tabular}

Soberon (2017) argues that although American Sniper is a war film, it simultaneously employs the conventional codes and themes of the classic Western genre. Following the Western genre, the film depicts the story of a man caught between civilization and wilderness. The Iraq war, in American Sniper, appears to be analogous to the Wild West, in the sense that America's involvement in Iraq represents a period of American history that remains wild and needs a violent reform to help it find a way to civilization. Therefore, the Middle East has become the new American frontier (Soberon, 2017). This situation can be considered as an allegory for the exceptional role of America as the protector of the world. They appear to serve as a sheepdog, fighting to save the weak against bullies on a global scale.

Viewing American Sniper as an adventure movie, Soltysik Monnet holds that Hollywood has continued "to directly or indirectly promote militarism since the beginning of the twentieth century, and American Sniper as an outstanding example of the adventure mode makes war quite attractive" (2018: 1377). In addition, the adventure genre that builds up the narrative movement of the film "helps to legitimate this relentless deployment of military violence by making it seem meaningful and justified" (Soltysik Monnet, 2018: 1380).

\section{EXPLANATION}

With the discourse practice of the film established, the key question now is "In which wider context does this discourse practice take place?". At this level, we try to explain this wider context, which is clear and evident in American culture, society and politics, with the help of the theory of the Clash of Civilizations, Orientalism, and the logic of exceptionalism. 
From the very beginning, the film reminds the audience of the unique role that the United States and its military forces play in the world. In this scene, the audience observes a montage of the effective childhood experiences that is overlaid with the voice of Kyle's father, revealing his worldview (Everett, 2017: 84):

\begin{abstract}
Wayne: There are three types of people in this world. Sheep, wolves and sheepdogs. Some people prefer to believe that evil doesn't exist in the world, and if it ever darkened their doorstep they wouldn't know how to protect themselves... those are the sheep. Then you got predators who use violence to prey on the weak. They're the wolves. Then there are those blessed with the gift of aggression and an overpowering need to protect the flock. These men are the rare breed that live to confront the wolf - They are the sheepdog.
\end{abstract}

Not surprisingly, American Sniper has succeeded in gaining enormous popularity, as it convincingly unites the ambitions of American exceptionalism that has always been successful in winning public favour. The idea that America is a unique country blessed with power, courage and desire to be a benevolent advocate for 'sheep' is completely in line with the ideology of exceptionalism during the Second World War. This very fundamental ideology remains constant despite the change in the conditions (Everett, 2017).

In another scene, the conversation between Chris and Taya makes them the subject of the West's discourse of exceptionalism.

Chris: I'd lay down my life for my country.

Taya: Why?

Chris: It's the greatest country on Earth. I'd do everything I can to protect it.

In this conversation, Chris acknowledges America as the best country in the world, and is ready to give his life for it, something that stems from American logic of exceptionalism. America's exceptionalism suggests that the spiritual superiority, the specific democratic and revolutionary roots, the political system, the social organization, the cultural and religious heritage, and the values of the United States serve to legitimize its policies. In the film, we see the only Iraqi family that is not involved in violence, remaining completely helpless with no possible means to defend or save itself. The family represents a stereotype of the Arabs and Muslims who need to be saved by the Western world. It stays there in the film to show the Iraqi people need to be defended and saved by the US fighting forces. In this scene, the logic of missionaryism of the discourse of exceptionalism gets highlighted:

Chris: Look, I want to help you out. But I need something. I need phone numbers, address and names. You have to give me something. You give me a name, and we will take care of it. I can promise you that. We will give you safety.

Here the American soldier promises security to the Iraqi man regardless of the fact that the US has occupied Iraq in an invasion of the Middle East. The implicit semantic implications of linguistic and visual signs of various episodes of the film are the inability of Iraqis to provide their own security and their need for a liberating power, that is, the United States of America. The film also reproduces the notions of 'Orientalism', based on which the cultures, values and nations of the East in general and of the Middle East in 
particular, appear to be inferior against those of the West. The film, of course, seeks to persuade the American public's opinion about the cause of the presence of the Americans in the Middle East and Iraq. Chris Kyle repeatedly insists that their war is to protect their own families, cities and the country:

Taya: Tell me why you do it.

Chris: Babe, I do it for you. I do it to protect you.

In order to persuade the public's opinion, the film introduces the Islamic world with attributes such as "animalization", "barbarism", "brutality", "conflict and violence", "destruction and backwardness", "cowardly and terrorist". As a result, the Islamic world and the Islamic societies are inherently an enemy to Western civilization due to the above features and should be defended by a pre-emptive attack on it from Western civilization and its achievements to prevent such events as the attacks on the embassies, military bases and September 11.

Animalisation occurs when 'Other' is described as an unrestrained wild monster, as savages who fail to control their animalistic tendencies, and their living conditions reflect their animality. In American Sniper, this 'Other' represents the Iraqis. The animalization of the 'Other' begins quite early in the film with a mother with her son. Immediately after this scene, with Chris Kyle targeting his sniper at the boy, there is a flashback to Chris Kyle shooting the first deer in his life; this scene juxtaposes the boy with the animal. Returning from the flashcard, the viewer sees Chris Kyle shooting the boy. Showing the mother who shows no signs of sadness for her dead child - even for a short moment - makes her look like a careless, murderous, expressionless and impassive machine. This initial scene marks the tone of 'barbarism' reflecting that the Arab and Muslim people are very weak and feeble (Karizat, 2017).

Chris Kyle and the other American soldiers always call them wild when they talk about the Iraqis. This is very evident when Chris Kyle and his friend talk about wedding rings:

Friend: 'I got the ring'

Chris Kyle: 'From here?'

Friend: 'F*'ck yea, it's so much cheaper here.'

Chris Kyle: 'Dude, you bought it from savages. How do you know it's not blood diamond?'

The constant reference to all Iraqis as the wild reduces the value of their lives and serves to justify many killing scenes in the film (Karizat, 2017). American Sniper paints all Muslim men, women and children as potential terrorists (Foody, 2018), and all the Iraqi people are shown to be merciless, greedy and inherently violent (Soltysik Monnet, 2018).

Overall, the Arabs are presented as a threat in the film at different levels. At one level, the stereotypes and codes associated with Orientalist discourse are used to this end. For instance, Muslim ominous and threatening slogans are heard in the battlefield at night; women are shown to be completely submissive and obedient; they remain silent behind their burkas when men are speaking; brutality and barbarism are seen as an inbuilt 
character of the Arab; finally, the film links the entire Middle East to the international terrorist network by showing a crowd of terrorists, rebels and insurgents from Iraq, Jordan and Syria (Soberon, 2017). While American Sniper shows a legendary hero who saves many and kills many others in honour of his nation on the surface level, "it unconsciously injects hatred, disgust and monolithic views about the east", on the deeper level (Ullah and Shahzor, 2017: 172).

The film attempts to back up the idea of the clash between Islamic and Western civilizations by showing the attack on the US embassy and the World Trade Towers. In fact, the broadcast of the same events encourages Chris Kyle to go to war and protect his country. The idea of the Clash of Civilizations has, in fact, transformed the basic and longstanding claim of Orientalism, that is, "superiority of the West and its mission of civilization building in a globalized world", into a new cultural discourse called 'Islamophobia' and its associate battle of the media (Stein and Salime, 2015: 384). Bazian (2018: 1) maintains that "Islamophobia is an ideological construct that emerges in the post-Cold War era with the intent to rally the Western world and the American society at a moment of perceived fragmentation" when the Soviet Union began to collapse in a rapidly changing world system. Thus, Islamophobia serves as the post-Cold War ideology that crafts the Western and American Self.

In brief, the review of the film at this level reveals that social structures have reproduced the film and discursive order of the society. In other words, American Sniper beats on the drum of war between the Western civilization and Islam, introducing Muslims as 'Other', and making America an exceptional country that should be protected against the Muslim extremists.

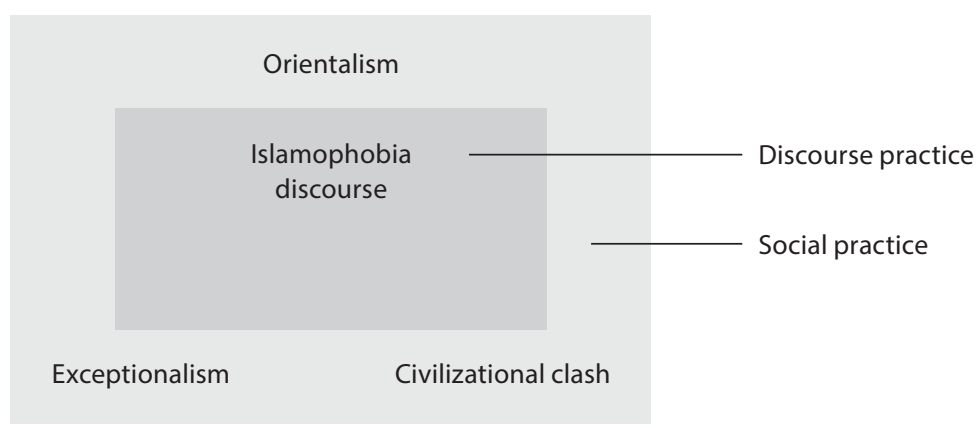

Figure 3.

Discourse of American Sniper 


\section{CONCLUSION}

In critical discourse analysis, language is not considered as a transparent mirror opening up the facts to everything. It rather reflects the truths in a distorted way under the influence of many external and internal factors which disclose the covert and overt power of the social and historical institutions in the distortion and the way it happens. In other words, the language of the film is not neutral and impartial at all. The language in its covert form has a discourse capacity larger than itself. The distance between the film language and reality fills the interests and ideology of discourses. The main purpose of the critical discourse analysis is the discovery of these very strategies and instruments of discourse that leads to the creation of domination and inequality in society and the crystallization of this inequality in language. Based on these theoretical foundations, this article has reviewed the naturalized discourses in American Sniper, as a product of Hollywood cinema. Since the beginning of the $20^{\text {th }}$ century, Hollywood, as the major player in the media field in the West, has helped to reproduce the logic of exceptionalism in American politics and created a new hegemony for the country. During the Cold War, communism and its danger succeeded in providing the necessary conceptual tools to the Western media. However, with the collapse of the Soviet Union in 1989, the unipolar of the world and the end of the Cold War, the Western media, especially Hollywood, replaced the threat of communism with the danger of Islam as an emerging power to fill the vacuum of 'Other-phobia'. Similarly, after September 11, Islamophobia came to assume a more complex form. It began to turn from a hidden trend and isolated subculture in Western societies into an influential and inclusive trend at all levels including Hollywood.

The critical analysis of the discourse of American Sniper at the three levels of description, interpretation, and explanation has shown that it reproduces the deeply rooted discourse of exceptionalism in the United States' cultural and political arenas. This discourse, as Said (1979) also points out, involves a marked contrast between the West as 'Self' and Islam as 'Other'. In American Sniper, at the description level, this 'Self' gets reproduced with a co-occurrence of such words as "duty", "sheepdog", "patriotic", "myth", "sacrifice", and "service" quite positively. In contrast Muslim as the 'Other' is negatively represented with words like "wolf", "new savage", "the wild", "evil people", "rubbish" and "bad guy". The interpretation of the film at the second level and the examination of its intertextual aspect has clarified that the film falls within the dominant atmosphere of Hollywood, which includes the discourse practice of 'Islamophobia' and represents the same concepts and symbols which exist in other films of the same trend. Consequently, the role of the reproduction and naturalization of this discourse can be rightly deduced in American Sniper. The analysis of the film at the level of explanation has also revealed that the roots of this discourse practice can be sighted in the logic of American exceptionalism, Orientalism, and clash between the Western and Islamic civilizations. Overall, it seems that the film intends to follow the same path of the dominant discourse and reproduce it in one way or another. In conclusion, American Sniper does not go beyond the scope of the Self/Other exceptionalism discourse prevailing in the cultural and political areas in the United States of America and tries to naturalize this discourse. 


\section{References}

>Bazian, Hatem (2018) Islamophobia, "Clash of Civilizations", and Forging a Post-Cold War Order. Religions 9: 1-13. https://doi.org/10.3390/rel9090282.

$>$ Belgrad, Doug; Cantillon, Elizabeth, Handleman, Max, and Banks, Elizabeth (Producers), and Banks, Elizabeth (Director) (2019) Charlie's Angels. [Motion picture]. United States: Columbia Pictures.

>Besson, Luc (Producer) and Morel, Pierre (Director) (2008) Taken. [Motion picture]. France: EuropaCorp.

$>$ Bigelow, Kathryn; Boal, Mark; Chartier, Nicolas, and Shapiro, Greg (Producers) and Bigelow, Kathryn (Director) (2009) The Hurk Locker. [Motion picture]. United States: Voltage Pictures. >Bigelow, Kathryn; Boal, Mark, and Ellison, Megan (Producers) and Bigelow, Kathryn. (Director) (2012) Zero Dark Thirty. [Motion picture]. United States: Columbia Pictures.

>Bourdieu, Pierre (1991) Language and symbolic power. Harvard: Harvard University Press. >Bush, George W. (2001) Remarks by the President Upon Arrival. https://georgewbushwhitehouse. archives.gov/news/releases/2001/09/20010916-2.html (18.3.2019).

>Callahan, Patrick (2004) Logics of American foreign policy: theories of America's world role. New York: Pearson.

$>$ Cameron, James, and Austin, Stephanie (Producers) and Cameron, James (Director) (1994) True Lies. [Motion picture]. United States: Lightstorm Entertainment.

$>$ Chava, Frankfort and Nachmias, David (2000) Research methods in the social sciences. New York: Worth Publishers.

>Cohen, Sacha; Berg, Alec and Mandel, David (Producers) and Charles, Larry (Director) (2012) The Dictator. [Motion picture]. United States: Four By Two Films.

>Cohen, Eliot A. (2001, November 20) World War IV. The Wall Street Journal. https://www.wsj.com/ articles/SB1006219259392114120 (13.2.2019)

>Cox, Michael (2003) The empire's back in town: or America's imperial temptation-again.

Millennium 32 (1): 1-27. https://doi.org/10.1177/03058298030320010101.

>Danesi, Marcel (2009) Opposition theory and the interconnectedness of language, culture, and cognition. Sign Systems Studies 37 (1-2): 11-42. https://doi.org/10.12697/sss.2009.37.1-2.02.

$>$ Danesi, Marcel (2018) Popular culture: Introductory perspectives. Lanham: Rowman and Littlefield. $>$ De Tocqueville, Alexis (2003) Democracy in America (Vol.10), Washington, DC: Regnery Publishing. $>$ Epstein, Adam (2015, March 15) American Sniper, the top-grossing film in the US last year, is the highest-earning war movie of all time. QUARTZ. https://qz.com/358562/(20.3.2019).

>Everett, Bryan (2017) American Exceptionalism in the Film Industry of the Middle Twentieth Century. http://digitalcommons.northgeorgia.edu/histphil_etd/7 (29.2.2019).

>Faimau, Gabriel (2015) The Conflictual Model of Analysis in Studies on the Media Representation of Islam and Muslims: A Critical Review. Sociology Compass 9 (5): 321-335. https://doi.org/10.1111/ soc4.12264.

$>$ Fairclough, Norman (1989) Language and power. New York: Longman.

>Fairclough, Norman (1992) Discourse and social change. Cambridge: Polity press.

$>$ Fairclough, Norman (1995) Critical Discourse Analysis. London: Longman.

>Foody, Kathleen M. (2018) Muslims in the American Media: From Texts to Affects. Journal of Islamic Studies 29 (2): 230-251. https://doi.org/10.1093/jis/etx089.

>Fox, Rachel (2018) Capturing Iraq: Optical Focalization in Contemporary War Cinematography. Interventions: International Journal of Postcolonial Studies 20 (4): 470-487. https://doi.org/10.1080/136 $9801 x .2017 .1421030$.

>Fukuyama, Francis (2001, Oct. 11) The west has won. The Guardian. https://www.theguardian.com/ world/2001/oct/11/afghanistan.terrorism30 (3.03.2019).

>Galvin, John (1993, April 2) Der Islam - Gefahr für die Welt?, Zeit. https://www.zeit.de/1993/14/derislam-gefahr-fuer-die-welt (26.3.2019).

>Garaudy, Roger (2004) Qu'est-ce que l'anti-américanisme? http://www.philosophie.org/garaudy1. html (17.3.2019). 
$>$ Hajaig, Hadi (Producer) and Hajaig, Hadi (Director) (2012) Cleanskin. [Motion picture]. United Kingdom: The UK Film Studio.

>Hampton, Tim and Mount, Thom (Producers) and Polanski, Roman (Director). (2004).

Frantic. [Motion picture]. United States: Warner Bros.

$>$ Hervik, Peter (2015) What is in the Scandinavian Nexus of "Islamophobia, Multiculturalism, and Muslim-Western Relations"? Intersections. East European Journal of Society and Politics 1 (1), 66-82. https://doi.org/10.17356/ieejsp.v1i1.29.

>lbrahim, Dina (2010) The framing of Islam on network news following the September 11th attacks. International Communication Gazette 72 (1): 111-125. https://doi.org/10.1177/1748048509350342. $>$ Jay, Martin (1984) Adorno. Harvard: Harvard University Press.

>Karim, Karim H. (2006) American media's coverage of Muslims: The historical roots of contemporary portrayals, pp. 116-127 in Poole, Elizabeth and Richardson, John. E. (eds) Muslims and the news media. London: I. B. Tauris.

>Karizat, Nadia (2017) One College Student's Analysis on Representation in the Film American Sniper. https://www.huffingtonpost.com/nadia-karizat/one-college-studentsanal_b_7424352.html (18.3.2019).

>Khamenei, Ali (2015, February 17) American Sniper film 'encourages violence against Muslims. Independent. https://www.independent.co.uk/news/world/middle-east (9.2.2019).

>Kilani, Munzer (2008) Orientalism and Occidentalism: The Invention of the Other in Anthropological Discourse, pp.10-16 in Labib,Tahar (ed.) Imagining the Arab Other: How Arabs and Non-Arabs View Each Other. London: I. B. Tauris.

>Menchawi Fawal, Obeida (2013) The Representations of Islam and Muslims in popular media:

Educational Strategies and to develop critical media literacy. Master thesis. Montreal:

Concordia University.

$>$ Neufeld, Mace and Rehme, Robert (Producers) and Noyce, Phillip (Director) (1987) Patriot Games. [Motion picture]. United States: Paramount Pictures.

$>$ Nye, Joseph S. (2004) Soft power: The means to success in world politics. New York.: Public affairs. >Obst, Lynda and Zwick, Edward (Producer) and Zwick, Edward (Director) (1998) The Siege [Motion picture]. United States: Twin River Productions.

$>$ O'Sullivan, John L. (1839) The great nation of futurity. The United States Democratic Review 6 (23): 426-430.

>Poole, Elizabeth and Richardson, John (2010) Muslims and the news media. London: IB Tauris. $>$ Ralph, Diana (2006) Islamophobia and the "War on Terror": The Continuing Pretext for U. S. Imperial Conquest, pp. 261-298 in Zarembka, Paul (ed.) The Hidden History of 9-11-2001. Bingley: Emerald Group Publishing Limited.

$>$ Reiner, Rob (Producer and Director) (1995) The American President. [Motion picture]. United States: Columbian Pictures.

$>$ Robinson, Nick (2015) Have You Won the War on Terror?. Journal of International Studies 43 (2): 450-470. https://doi.org/10.1177/0305829814557557.

$>$ Rojecki, Andrew (2008) American Exceptionalism and the War on Terror. Political Communication 25 (1): 67-88. https://doi.org/10.1080/10584600701807935.

$>$ Said, Edward W. (1979) Orientalism. New York, NY: Vintage.

>Said, Edward W. (2008) Covering Islam: How the media and the experts determine how we see the rest of the world. New York: Random House.

>Samueles, Ron; Wizan, Joe, Lenart, Lou and Elders, Kevin (Producers) and Furie, Sidney (Director) (1986) Iron Eagle. [Motion picture]. United States: TriStar Pictures.

>Sardar, Ziauddin and Merryl Wyn Davies (2003) Why do people hate America? Newburyport, MA: Red Wheel Weiser.

>Saussure, Ferdinand (1916) Course in General Linguistics, edited by Charles Bally and Albert Sechehaye. Trans. Roy Harris. La Salle, IL: Open Court.

>Sayyid, Salman (2015) A fundamental fear: Eurocentrism and the emergence of Islamism. London: Zed Books Ltd. 
>Shaheen, Jack G. (2012) Reel bad Arabs: How Hollywood vilifies a people. New York: Interlink Publishing.

>Soberon, Lennart (2017) The Old Wild West in the New Middle East: American Sniper (2014) and the Global Frontiers of the Western Genre. European journal of American studies 12 (12-2): 1-18. https://doi.org/10.4000/ejas.12086.

$>$ Soltysik Monnet, Agnieszka (2018) American War Adventure and the Generic Pleasures of Military Violence: Clint Eastwood's American Sniper. The Journal of Popular Culture 51 (6): 1376-1397. https:// doi.org/10.1111/jpcu.12735.

$>$ Stein, Arlene and Salime, Zakia (2015) Manufacturing Islamophobia: rightwing pseudodocumentaries and the paranoid style. Journal of Communication Inquiry 39 (4): 378-396. https://doi. org/10.1177/0196859915569385

>Szpunar, Piotr M. (2013) The Horror at Fort Hood: Disseminating American Exceptionalism. Media, Culture and Society 35 (2): 182-198. https://doi.org/10.1177/0163443712468607

$>$ Taibbi, Matt (2015, January 21) American Sniper'is almost too dumb to criticize. Rolling

Stone Magazine.

>Thatcher, Margaret (2002, 12 February) Islamism is the new bolshevism. The Guardian. https:// www.theguardian.com/world/2002/feb/12/afghanistan.politics (13.4.2019).

$>$ Tokat, Murat and Akkaya, Mevlut (Producers) and Kırmızıgül, Mahsun (Director) (2010) Five

Minarets in New York. [Motion picture]. United States: Boyut Film.

$>$ Ullah, Inayat and Shahzor, Kulssom (2017) Cultural (Mis)Appropriation, Ideological Essentialism and Language: Analysis of Stereotyping in Hollywood Movie. International Journal of English Linguistics 7 (6): 171-177. https://doi.org/10.5539/ijel.v7n6p171.

$>$ Wasko, Janet (2003) How Hollywood Works. London: Sage Publication.

$>$ Williams, Raymond (2000) Advertising: The magic system. Advertising and Society Review 1 (1): 170195. https://doi.org/10.1353/asr.2000.0016.

>Wilsey, John (2017) Our Country Is Destined to be the Great Nation of Futurity: John L. O'Sullivan's Manifest Destiny and Christian Nationalism, 1837-1846. Relegions 8 (4): 1-17. https://doi.org/10.3390/ rel8040068.

>Zakaria, Fareed (2008) The post-American world. New York: Norton and Company.

>Zhang, Qiang and Li, Ke (2017) On Studies of the Representation of Islam and the Muslims in West Media and Factors behind Misrepresentation. Journal of Education and Culture Studies 1 (1): 69-92.

https://doi.org/10.22158/jecs.v1n1p69. 


\section{KRITIČKA ANALIZA POLITIČKOGA DISKURSA IZUZETNOSTI U FILMU AMERIČKI SNAJPER}

Hamdallah Akvani :: Abdolvahed Zarifi :: Hossein Fakhraei

SAŽETAK Politički diskurs obično se širi kroz druga diskurzivna područja. Jedno od područja kroz koje se politika može reproducirati jest područje popularne kulture, posebno filma. Štoviše, jezik služi kao posredujuća varijabla kroz koju se politički diskursi predstavljaju u medijima, više ili manje ideološki. Ovaj rad analizira jezik filma Američki snajper i njegov odnos s diskursom izuzetnosti u politici SAD-a. Ključno pitanje koje rad postavlja jest kako je diskurs Američkog snajpera povezan s tri razine diskursa izuzetnosti. Analiza tri diskurzivne razine filma - deskripcije, interpretacije i objašnjenja - koje se temelje na Faircloughovu modelu, otkriva da film prati dominantni holivudski diskurs uokvirivanja islama i Srednjeg istoka, tzv. diskurs 'islamofobije' te prikazuje islam kao "drugog". Diskurs filma dio je šire društvene akcije koja je podudarna s konceptom političkog jezika izuzetnosti.

\section{KLJUČNE RIJEČI}

ISLAMOFOBIJA, IZUZETNOST, POLITIČKO PODRUČJE, KRITIČKA ANALIZA DISKURSA, AMERIČKI SNAJPER

Bilješka o autorima

Hamdallah Akvani :: Odsjek za politologiju, Fakultet za humanističke studije, Sveučilište Yasouj, Iran:: akvani@yu.ac.ir

Abdolvahed Zarifi :: Odsjek za engleski jezik, Fakultet za humanističke studije, Sveučilište Yasouj, Iran :: vzarifi@yu.ac.ir

Hossein Fakhraei :: Odsjek za politologiju, Fakultet za humanističke studije, Sveučilište Yasouj, Iran :: hosseinfakhraee72@gmail.com 